\title{
Karakterisasi Fenotip dan Indeks Similaritas Isolat Actinomycetes yang Memiliki Kemampuan Antibakteri terhadap Escherichia coli dan Staphylococcus aureus
}

\author{
Wahyu Nur Sulistyanto ${ }^{1 *}$, Guntur Trimulyono ${ }^{1)}$ \\ ${ }^{1)}$ Program Studi Biologi, Fakultas Matematika dan Ilmu Pengetahuan Alam, Universitas Negeri Surabaya, \\ Jl. Ketintang Surabaya, Jawa Timur \\ *) Alamat korespondensi: wahyunut@gmail.com
}

\begin{abstract}
ABSTRAK
Eksplorasi kandidat mikrobia penghasil antibiotik semakin meningkat sebagai solusi banyaknya bakteri resisten terhadap antibiotik yang telah ada. Pada penelitian sebelumnya telah didapatkan empat isolat Actinomycetes yaitu ACB34a, ACB44c, ACB54c dan ACB55c yang memiliki kemampuan antibakteri, sehingga diperlukan identifikasi jenis isolate sampai tingkat Genus. Tujuan penelitian ini adalah mengidentifikasi jenis isolat yang terpilih (ACB34a, ACB44c, ACB54c dan ACB55c) berdasarkan karakteristik fenotip, dan menentukan indeks similaritas antarisolatnya. Identifikasi isolat dilakukan menggunakan karakter fenotip yang meliputi morfologi, fisiologi, biokimia dan dilanjutkan pengolahan numerik. Analisis data secara deskriptif dan numerik menggunakan Clad97. Hasil penelitian menunjukkan dua isolat Actinomycetes (ACB34a dan ACB55c) memiliki kemiripan dengan Genus Actinomadura. Sedangkan dua isolate berikutnya, yaitu ACB44c dan ACB54c masing-masing mirip dengan Genus Nocardia dan Streptomyces. Nilai indeks similaritas antara isolat ACB34a dan ACB55c adalah 0,856, selanjutnya isolat ACB54c dan ACB44c memiliki kesamaan 0,788, dan isolat ACB55c dan ACB34a memiliki kesamaan sebesar 0,7788.
\end{abstract}

Kata kunci: Actinomycetes, antibakteri, indeks similaritas, karakteristik fenotip

\section{Phenotypic Characterization and Similarity Indices of Actinomycetes Isolates with Antibacterial Ability against Escherichia coli and Staphylococcus aureus}

\author{
Wahyu Nur Sulistyanto ${ }^{1}{ }^{*}$, Guntur Trimulyono ${ }^{1)}$ \\ 1)Biology Study Program, Faculty of mathematics and Natural Sciences, Universitas Negeri Surabaya, Ketintang Street, \\ Surabaya, East Java \\ *) Email: wahyunut@gmail.com
}

\begin{abstract}
Exploration of antibiotic-producing microbes is getting increase as a solution to the increasing number of resistant bacteria to existing antibiotics. Previous studies have shown that four isolates of Actinomycetes namely ACB34a, ACB44c, $\mathrm{ACB54c}$ and $\mathrm{ACB55c}$ have antibacterial activities therefore further identification is required. The purpose of this study was to identify the Actinomycetes isolates (ACB34a, ACB44c, ACB54c and ACB55c) based on phenotypic characteristics, and to determine the similarity index among isolates. Isolates identification was performed using phenotypic characters including morphology, physiology, biochemistry, and then followed by numerical processing. Analysis of data was conducted descriptively and numerically using Clad97. The results showed that the four Actinomycetes isolates (ACB34a, ACB44c, ACB54c dan ACB55c) have similarities to the character of different genus, which were Actinomadura, Nocardia, Streptomyces and Actinomadura, respectively. The similarity index between isolate ACB34a and ACB55c was 0.856, isolate $\mathrm{ACB54c}$ with $\mathrm{ACB} 44 \mathrm{c}$ had similarity index of 0.788 , while between isolate $\mathrm{ACB55c}$ and $\mathrm{ACB34a}$ was 0.7788 .
\end{abstract}

Keywords: Actinomycetes, antibacteria, phenotypic characteristics, similarity index

\section{PENDAHULUAN}

Actinomycetes diketahui telah banyak menyumbang sebagai sumber antibiotik yang ada saat ini. Eksplorasi sumber-sumber antibiotik semakin ditingkatkan sebagai solusi semakin banyaknya bakteri resisten terhadap antibiotik yang telah ada. Actinomycetes diketahui menjadi penghasil senyawa bioaktif yang berpengaruh terhadap dunia industri [1]. 
Kemampuan dalam menghasilkan banyak senyawa bioaktif yang berhasil diisolasi dan dimanfaatkan peneliti antara lain antibiotik, antikanker, antitumor, dan immunosupresan dengan dugaan jenis senyawa bakteri yang ditemukan Erythromycin, Tetracycline, Rifampicin, Polymyxin dan Chloramphenicol [2]. Berbagai senyawa bioaktif tersebut memiliki potensi antibakteri yaitu dengan merusak dinding sel atau merusak sintesis dinding sel, dan merusak asam nukleat yang menyebabkan peningkatan tekanan osmotik yang mengakibatkan sel lisis. Senyawa antimikroba yang ideal adalah senyawa yang memiliki toksisitas selektif.

Keragaman mikroba pada rhizosfer merupakan hasil interaksi dan adaptasi yang dapat dimungkinkan adaptif atau resisten terhadap toksin yang dihasilkan tanaman. Kemampuan tersebut memungkinkan mikroba menghasilkan metabolit sekunder yang spesifik seperti antibiotik. Tanah di sekitar akar atau rhizosfer mengandung banyak bahan organik yang dapat mendukung peningkatan mikroba aktif daripada tanah biasa atau tanah curah [34].

Pada penelitian sebelumnya telah berhasil mengisolasi bakteri Actinomycetes isolat ACB34a dan ACB55c yang diduga anggota Genus Actinomadura, isolat ACB44c diduga anggota Genus Necordia serta isolat ACB54c diduga anggota Genus Streptomyces [5]. Karakterisasi lanjutan perlu dilakukan untuk melengkapi hasil penelitian sebelumnya dan mendapatkan nilai indeks similaritas menggunakan CLAD97. Pengolahan data untuk menentukan indeks similaritas banyak tersedia seperti MVSP dan lainnya. Penggunaan MVSP memiliki kelemahan yaitu membutuhkan byte perangkat PC yang khusus dalam penginstalannya. Di sisi lain, penggunaan Clad97 lebih mudah jika dilihat dari langkah, prosedur preparasi dan pengerjaannya. Oleh karena itu, pada penelitian ini Clad97 digunakan untuk menentukan tingkat kesamaan antarisolat. Nilai output similaritas dalam rentang skala $0,00-1,00$ [6].

Tujuan penelitian ini adalah untuk mengidentifikasi jenis isolat yang terpilih (ACB34a, ACB44c, ACB54c dan ACB55c) sampai tingkat Genus berdasarkan karakteristik fenotip, dan menentukan indeks similaritas antar isolatnya.

\section{METODE PENELITIAN}

Waktu dan tempat penelitian. Penelitian ini dilakukan pada bulan Februari sampai Maret 2019. Isolat Actinomycetes didapatkan dari penelitian sebelumnya yang diisolasi dari rhizosfer tanaman tebu dari kebun tebu daerah Kamal, Bangkalan. Isolat-isolat tersebut (ACB34a, ACB44c, ACB54c dan ACB55c) memiliki kemampuan antibakteri terhadap E. coli dan S. aureus [5]. Penelitian dilakukan di Laboratorium Mikrobiologi Balai Karantina Ikan, Pengendalian Mutu dan Keamanan Hasil Perikanan (KIPM) Kelas I Surabaya.

Persiapan media. Media pertumbuhan yang digunakan antara lain Starch Casein Agar (SCA), Nutrient Broth (NB), dan Nutrient Agar (NA), Media SCA dibuat dengan cara mencampurkan 10 g soluble starch, $2 \mathrm{~g} \mathrm{~K}_{2} \mathrm{HPO}_{4}, 2 \mathrm{~g} \mathrm{KNO}$, $0,3 \mathrm{~g}$ kasein, 0,05 g MgSO4.7 $\mathrm{H}_{2} \mathrm{O}, 15 \mathrm{~g}$ agar dalam $1 \mathrm{~L}$ aquades [7]. Media NB dibuat dengan mencampurkan $8 \mathrm{~g}$ NB dalam $1 \mathrm{~L}$ aquades. Media NA dibuat dengan mencampurkan NB menggunakan agar $1,5 \%$. Masing-masing media disterilisasi menggunakan autoklaf pada suhu $121^{\circ} \mathrm{C}$ dengan tekanan $1 \mathrm{~atm}[8]$.

Kultur isolat Actinomycetes terpilih. Tahapan kultur dilakukan dengan streak isolat terpilih pada media SCA miring diinkubasi selama tujuh hari untuk mendapatkan koloni dengan ukuran besar [9].

Karakterisasi fenotip isolat Actinomycetes. Karakterisasi fenotip ini meliputi karakter morfologi, fisiologi, dan biokimia. Karakterisasi morfologi sel dilakukan melalui pewarnaan Gram. Tahapan pewarnaan Gram dilakukan dengan mempersiapkan crystal violet, iodine, alkohol $96 \%$, dan safranin. Hasil pewarnaan Gram menunjukkan Gram positif jika berwarna biru/ungu, dan Gram negatif jika berwarna merah [8].

Karakterisasi fisiologi meliputi uji oksidase, uji katalase, ketahanan pada suhu berbeda, dan ketahanan pada berbagai kadar garam. Uji oksidase dilakukan menggunakan oxydase strips. Uji katalase dilakukan dengan menggunakan reagen $\mathrm{H}_{2} \mathrm{O}_{2} 3 \%$ yang diteteskan (1-2 tetes) pada kultur. Pengujian ketahanan suhu diawali bakteri disuspensikan pada media NB. Kemudian suspensi tersebut diinkubasi dengan suhu yang berbeda antara lain $25^{\circ} \mathrm{C}, 37^{\circ} \mathrm{C}, 40^{\circ} \mathrm{C}$ dan $45^{\circ} \mathrm{C}$ dengan lama inkubasi $24 \mathrm{jam}$. Pertumbuhan suatu bakteri dapat diketahui dengan mengamati tingkat kekeruhannya [10]. Ketahanan $\mathrm{NaCl}$ dilakukan dengan pembuatan NB dengan kadar $\mathrm{NaCl} 5 \%$ dan $10 \%$. Kemudian biakan diinokulasikan dan diinkubasi 
selama 24 jam. Pertumbuhan bakteri dapat diketahui dengan kekeruhan pada tabung [10].

Karakterisasi biokimia meliputi beberapa jenis uji seperti MIO, TSIA, reduksi gula, urea, arginin, sitrat, oksidatif/ fermentasi, aesculin, lysin dan MRVP. Uji MIO merupakan uji untuk mengetahui motilitas, indole dan ornithin menggunakan media MIO. Isolat diinokulasikan dengan cara kultur ditusukan ke dalam 2/3 bagian media MIO [11]. Uji TSIA merupakan uji untuk mengetahui inokulan dapat menghasilkan acid/alkali serta $\mathrm{H}_{2} \mathrm{~S}$ menggunakan media TSIA. Kultur diinokulasi dengan cara ditusuk hingga dasar tabung media TSIA [12]. Uji reduksi gula dengan cara menumbuhkan isolat pada media yang mengandung berbagai jenis gula seperti glukosa, laktosa, sukrosa, arabinosa, manitol, inositol, maltosa, dulcitol, xylose, salicin, sorbitol, trehalosa.

Uji urea merupakan pengujian untuk mengetahui kemampuan bakteri dalam mereduksi urea. Pengujian dilakukan dengan streak pada media urea miring. Indikasi positif jika media berwarna merah muda [13]. Uji arginin adalah salah satu uji bakteri yang digunakan untuk mengetahui kemampuan suatu bakteri dalam mendegradasi argnin [14]. Uji ini dilakukan dengan menginokulasikan isolat pada media argnin broth. Hasil positif jika media menjadi keruh, sedangkan negatif apabila media tetap jernih [12].

Uji sitrat menggunakan media simmon's citrate dengan teknik streak pada media miring simmon's citrate. Hasil positif ditunjukkan dengan warna biru pada bagian dalam atau permukaan dari medium [1]. Uji oksidatif/ fermentatif $(\mathrm{O} / \mathrm{F})$ merupakan salah satu uji untuk mengetahui sifat oksidasi atau fermentasi suatu bakteri pada glukosa. Uji ini menggunkaan dua tabung, satu media diberi parafin cair sedangkan yang lain tidak. Jika kedua tabung berwarna kuning membuktikan bakteri bersifat fermentatif (F), apabila yang tidak diberi parafin memiliki warna hijau diketahui bahwa bakteri bersifat oksidatif $(\mathrm{O})$ dan jika kedua tabung berwarna hijau menunjukkan no reaction (NR). Tujuan pemberian parafin cair pada media $\mathrm{O} / \mathrm{F}$ adalah sebagai pembanding untuk membuktikan apakah bakteri tersebut mampu melakukan respirasi tanpa menggunakan oksigen bebas (respirasi anaerob) $[13,15]$.

Uji MRVP dilakukan dengan
menumbuhkan isolat pada media MRVP kemudian diinkubasi selama 24 jam. Biakan bakteri pada media uji MRVP dibagi menjadi dua. Tabung reaksi pertama ditetesi dengan reagen Methyl Red (MR) hingga setengah dari banyak media di tabung. Kemudian tabung reaksi kedua ditetesi dengan reagen VP1 ( $\alpha$-naphthol) sebanyak $1 / 4$ total media MRVP di tabung reaksi dan reagen VP 2 (KOH 40\%) sebanyak $1 / 4$ total media MRVP di tabung reaksi. Kemudian dikocok dan ditunggu hingga 15 menit. Uji MR dikatakan positif apabila terjadi perubahan warna menjadi merah dan negatif jika berwarna kuning. Sedangkan uji VP dikatakan positif jika berubah menjadi merah dan dikatakan negatif saat tidak terjadi perubahan atau berwarna kuning [12].

Uji aesculin dilakukan dengan menginokulasikan biakan pada media aesculin dan dihomogenasi, kemudian diinkubasi selama 24 jam. Hasil reaksi positif jika warna media berubah menjadi hitam. Uji lysin menggunakan media LIA dengan pembacaan positif diketahui jika warna media berubah menjadi ungu pada goresan dan kuning pada tusukan berarti dikatakan negatif [12].

Analisis deskriptif dan numerik. Hasil karakterisasi fenotip yang telah didapatkan, kemudian dianalisis menggunakan Profile Matching untuk mengetahui dugaan Genus isolat terpilih dan analisis numerik menggunakan software Clad97 untuk menghasilkan hasil indeks similaritas atau indeks kesamaan antarisolat terpilih. Indeks similaritas ditentukan pada hasil karakteristik fenotip dengan penulisan (+) sebagai hasil positif dan (-) sebagai hasil negatif. Hasil tersebut dipreparasi menggunakan aplikasi Programmers File Editor (PFE). Data dengan hasil (+) diganti dengan 1 dan (-) dengan angka 0 . Pengubahan tersebut dilakukan pada aplikasi CLAD97 untuk dihasilkan cladogram yang mencerminkan klasifikasi Operational Taxonomical Unit (OTU) [16].

\section{HASIL DAN PEMBAHASAN}

Empat isolat Actinomycetes yaitu ACB34a, ACB44c, ACB54c dan ACB55c dengan kemampuan antibakteri [5], kemudian dilakukan karakterisasi lanjutan berdasarkan karakter fenotip. Karakter keseluruhan isolat kemudian dianalisis menggunakan Profile Matching. Hasil dugaan isolat terpilih antara lain Actinomadura, Necordia dan Sterptomyces. Actinomycetes merupakan golongan bakteri yang menghasilkan metabolit sekunder. Actinomycetes menghambat sintesis dinding sel dari bakteri uji yang menyebabkan 
Tabel 1. Karakter fenotip isolat Actinomycetes

\begin{tabular}{|c|c|c|c|c|}
\hline Karakteristik & ACB34a & ACB44c & ACB54c & ACB55c \\
\hline Tumbuh di SCA & + & + & + & + \\
\hline Warna koloni & Putih & Putih & Krim & Putih \\
\hline Bentuk koloni & Circular & Circular & Circular & Circular \\
\hline Tepi & Entire & Entire & Entire & Entire \\
\hline Elevasi & Convex & Convex & Convex & Convex \\
\hline Permukaan & Kasar & Kasar & Kasar & Kasar \\
\hline Optik & Oраqие & Opaque & Opaque & Opaque \\
\hline Tumbuh di Oatmeal & + & + & + & + \\
\hline Miselium subtrat & Merah muda & Merah muda & Abu-abu & Putih \\
\hline Miselium aeral & Merah muda & Putih & Abu-abu & Abu-abu kemerahan \\
\hline Pigmentasi miselium & - & - & Kuning emas & - \\
\hline Morfologi & Branching rod & $\begin{array}{l}\text { Branching } \\
\text { rod }\end{array}$ & Branching rod & Branching rod \\
\hline Gram & + & + & + & + \\
\hline Antibakteri E. coli & - & $\begin{array}{c}+ \\
(3,5 \mathrm{~mm})\end{array}$ & $\begin{array}{c}+ \\
(0,7 \mathrm{~mm})\end{array}$ & - \\
\hline Golongan & - & Lemah & Lemah & - \\
\hline Antibakteri S. aureus & $+(3,2 \mathrm{~mm})$ & $\begin{array}{c}+ \\
(5,9 \mathrm{~mm})\end{array}$ & $\begin{array}{c}+ \\
(5,8 \mathrm{~mm})\end{array}$ & $\begin{array}{c}+ \\
(3,2 \mathrm{~mm})\end{array}$ \\
\hline Golongan & lemah & sedang & sedang & sedang \\
\hline \multicolumn{5}{|l|}{ Uji Fisiologi-biokimia } \\
\hline Oksidase & + & + & + & + \\
\hline Katalase & + & - & + & + \\
\hline $\mathrm{O} / \mathrm{F}$ & NR & NR & NR & NR \\
\hline TSIA, Gas, H2S & $\mathrm{Ak}$ & $\mathrm{Ak}$ & $\mathrm{Ak}$ & $\mathrm{Ak}$ \\
\hline LIA & - & - & - & - \\
\hline Motilitas & - & - & - & - \\
\hline Gelatin & + & + & + & + \\
\hline Indol & - & + & - & - \\
\hline Ornithin & - & - & - & - \\
\hline Arginin & - & - & + & - \\
\hline Simmon's Citrat & - & - & + & + \\
\hline Urease & + & + & - & - \\
\hline MR & - & + & - & - \\
\hline VP & - & - & - & - \\
\hline $\mathrm{Tb}$ & - & - & - & - \\
\hline Aesculin & - & - & - & - \\
\hline \multicolumn{5}{|l|}{ Reduksi Gula } \\
\hline Glukosa & + & + & + & + \\
\hline Laktosa & + & + & + & + \\
\hline Sukrosa & + & + & + & + \\
\hline Arabinosa & + & + & + & + \\
\hline Manitol & + & + & + & + \\
\hline Inositol & + & + & + & + \\
\hline Maltosa & + & + & + & + \\
\hline Dulcitol & + & + & + & + \\
\hline Xylose & + & + & + & + \\
\hline Salicin & + & + & + & + \\
\hline Sorbitol & + & + & + & + \\
\hline Trehalosa & + & + & + & + \\
\hline \multicolumn{5}{|l|}{ Pertumbuhan Bakteri } \\
\hline Pertumbuhan & Obligat Aerob & $\begin{array}{l}\text { Obligat } \\
\text { Aerob }\end{array}$ & Obligat Aerob & Obligat Aerob \\
\hline \multicolumn{5}{|l|}{ Kemampuan Hidup } \\
\hline Suhu $24^{\circ} \mathrm{C}$ & + & + & + & + \\
\hline Suhu $28^{\circ} \mathrm{C}$ & + & + & + & + \\
\hline Suhu $32^{\circ} \mathrm{C}$ & + & + & + & + \\
\hline Suhu $36^{\circ} \mathrm{C}$ & + & + & + & + \\
\hline $\mathrm{NaCl} 5 \%$ & + & + & + & + \\
\hline $\mathrm{NaCl} 10 \%$ & - & - & - & - \\
\hline Hasil Identifikasi & Actinomadura & Nocardia & Streptomyces & Actinomadura \\
\hline
\end{tabular}


peningkatan tekanan osmotik sel sehingga bakteri uji menjadi terhambat [23].

Berdasarkan keseluruhan hasil karakterisasi awal dan lanjutan, semua isolat kebanyakan memiliki karakter yang sama namun beberapa karakter menunjukkan perbedaan antarisolatnya (Tabel 1). Karakter yang berbeda antara lain katalase isolat
ACB44c negatif lainnya positif, indol isolat ACB44c positif lainnya negatif, Ornitin isolat ACB34a positif lainnya negatif, Arginin isolat ACB54c positif lainnya negatif, Simmon's citrate isolat ACB54c dan ACB55c positif sedangkan lainnya negatif, urease isolat ACB34a dan ACB44c positif sedangkan lainnya negatif, karakter MR isolat ACB44c positif lainnya negatif.

Tabel 2. Generic assignment (profile matching) isolat Actinomycetes terpilih yang diduga anggota Genus Streptomyces

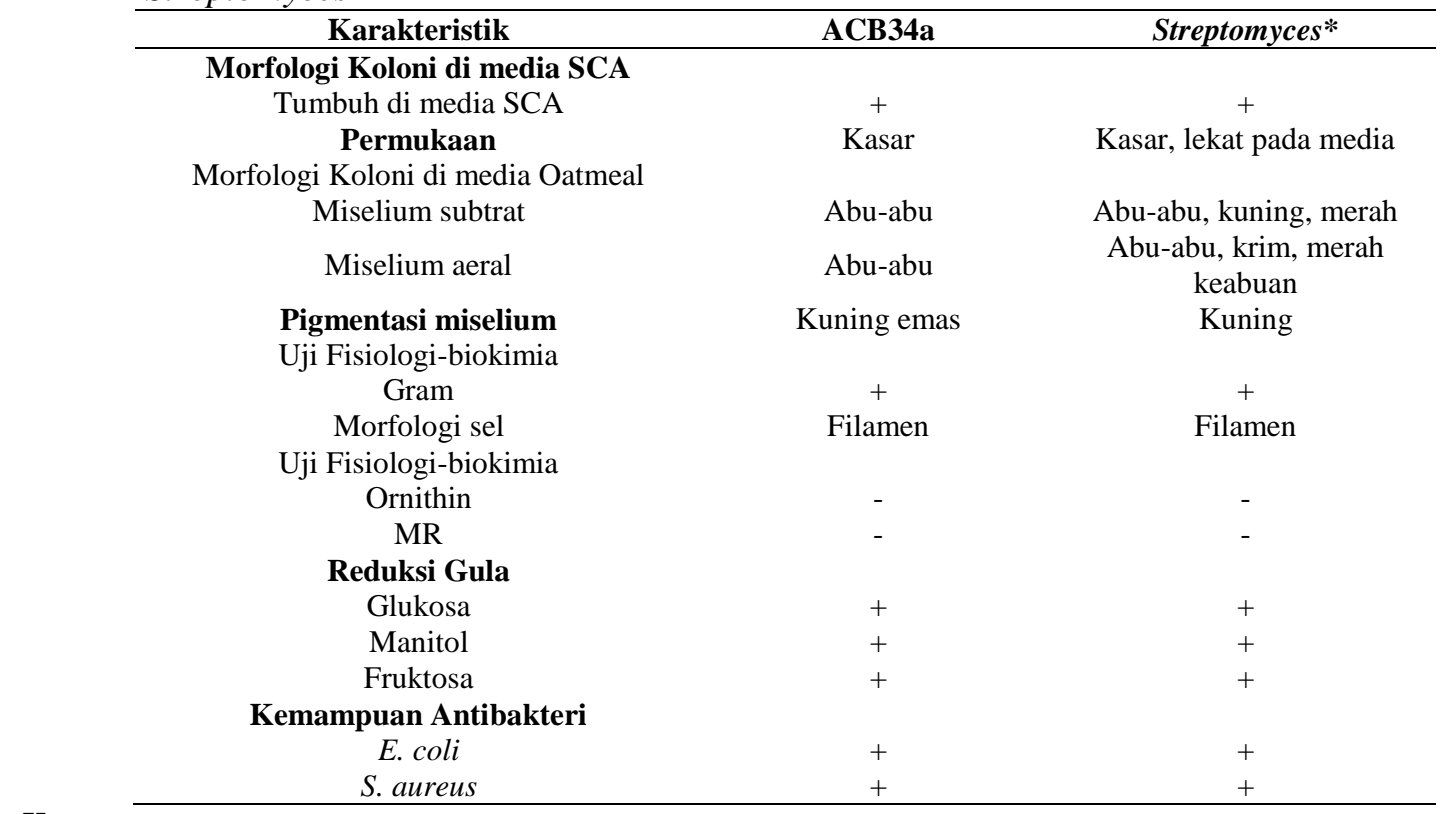

Keterangan:

(+) Dapat menghasilkan/ mereduksi/ dapat tumbuh/ tahan terhadap/ menggunakan

(-) Tidak dapat menghasilkan/ mereduksi/ dapat tumbuh/ tahan terhadap/ menggunakan

(NR) No reaction; (Ak) Alkaline *Sumber: [5, 11]; Metode: Penyocokan Generic Assignment (Profile Matching)

Tabel 3. Generic assignment (profile matching) isolat Actinomycetes terpilih yang diduga anggota Genus Necordia

\begin{tabular}{ccc}
\hline Karakteristik & ACB34a & Necordia* \\
\hline $\begin{array}{c}\text { Morfologi Koloni di media SCA } \\
\text { Tumbuh di media SCA }\end{array}$ & + & + \\
Morfologi Koloni di media Oatmeal & & Merah muda, putih, abu-abu, \\
Miselium subtrat & Merah muda & Putih, coklat, kuning \\
Miselium aeral & Putih & - \\
Pigmentasi miselium & - & \\
Uji Fisiologi-biokimia & & + \\
Gram & + & Filamen \\
Morfologi sel & Filamen & - \\
Motil & - & + \\
Gelatin & + & + \\
Indol & + & + \\
Reduksi Gula & & Obligat Aerob \\
Glukosa & + & + \\
Pertumbuhan & Obligat Aerob & + \\
\hline
\end{tabular}

Keterangan:

(+) Dapat menghasilkan/ mereduksi/ dapat tumbuh/tahan terhadap/ menggunakan

(-) Tidak dapat menghasilkan/mereduksi/ dapat tumbuh/tahan terhadap/ menggunakan

(NR) No reaction; (Ak) Alkaline *Sumber: [4, 11, 21]; Metode: Penyocokan Generic Assignment (Profile Matching) 
Tabel 4. Generic assignment (profile matching) isolat Actinomycetes terpilih yang diduga anggota Genus Actinomadura

\begin{tabular}{cccc}
\hline Karakteristik & ACB34a & ACB55c & Actinomadura* \\
\hline $\begin{array}{c}\text { Morfologi Koloni di media SCA } \\
\text { Tumbuh di media SCA }\end{array}$ & + & + & + \\
Morfologi Koloni di media Oatmeal & & & + \\
Tumbuh di media Oatmeal & + & + & Merah, coklat, \\
Miselium subtrat & Merah muda & Putih & putih, krim \\
Uji Fisiologi-biokimia & & & + \\
Gram & & + & + \\
Morfologi sel & + & Filamen & + \\
Gelatin & Filamen & + & + \\
Reduksi Gula & + & + & + \\
Maltosa & & + & + \\
Sukrosa & + & + & + \\
Arabinosa & + & + & + \\
Fruktosa & + & + & + \\
NaCl 5 \% & + & + & + \\
\hline
\end{tabular}

\section{Keterangan:}

(+) Dapat menghasilkan/ mereduksi/ dapat tumbuh/tahan terhadap/ menggunakan

(-) Tidak dapat menghasilkan/mereduksi/ dapat tumbuh/tahan terhadap/ menggunakan

(NR) No reaction; (Ak) Alkaline *Sumber:[18-22]; Metode: Penyocokan Generic Assignment (Profile Matching)

Hasil karakterisasi fenotip yang diperoleh dicocokkan karakter kunci dengan sumber utama Bergey's Manual of Determinative Bacteriology, kemudian dibuat tabel Generic Assignment (Profile Matching). Data tabel berupa penyandingan hasil karakterisasi dengan karakterisasi kunci genus yang diduga. Genusgenus yang diduga tersebut antara lain Actinomadura, Necordia dan Streptomyces.

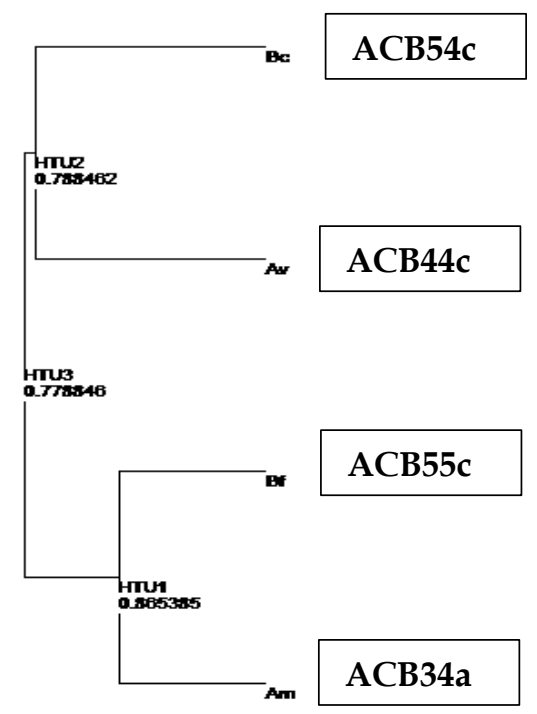

Gambar 1. Similaritas isolat Actinomycetes terpilih. HTU (Hypothetical Taxonomy Unit): Nodus internal dalam analisis fenetik/filogenetik

Hasil karakter penelitian sebelumnya [5] dan penelitian ini digabungkan untuk pengerjaan klasifikasi numerik (indeks similaritas). Karakterisasi saat skrining awal, skrining lanjutan dan uji kemampuan antibakteri pada penelitian sebelumnya juga diinput bersama dengan karakterisasi lainnya. Semua karakter kemudian dilakukan penyocokan dengan panduan buku Bergey's Manual serta literatur penelitian yang lainnya, serta dilakukan pengecekan key identification. Terdapat 52 uji pendukung karakterisasi bakteri Actinomycetes terpilih. Uji-uji tersebut juga dilakukan pada penelitian sebelumnya [17-22].

Berdasarkan hasil identifikasi isolat ACB54c merupakan Genus Streptomyces (Tabel 2). Rincian kesamaan hasil karakterisasi dengan beberapa literatur antara lain warna miselium subtrat abu-abu, memiliki warna miselium pigmen kuning, memiliki miselium aeral abuabu, suhu inkubasi optimal $20-37{ }^{\circ} \mathrm{C}$, ketahanan terhadap $\mathrm{NaCl} 3 \%$, arginin positif [21]. Uji gelatin positif dan memiliki kemampuan antibakteri terhadap E. coli dan S. aureus. Nonmotil, indol negatif, ornithin negatif, tergolong aerob, katalase positif, dapat mereduksi sitrat, alkaline pada uji TSIA [20]. Koloni berwarna krim [19]. Permukaan kasar dan melekat pada media. Dapat memfermentasi arabinosa, fruktosa, manitol, inositol, Gram positif, MR menunjukkan hasil negatif, oksidase positif, tanpa gas dan $\mathrm{H}_{2} \mathrm{~S}$ pada media TSIA [22].

Pada identifikasi isolat ACB44c menunjukkan masuk ke dalam anggota Genus Nocardia (Tabel 3). Rincian hasil kesamaan karakter kunci dari beberapa literatur antara lain menampakkan miselium subtrat berwarna merah muda [19], tidak menghasilkan pigmen pada 
subtrat, Gram positif, tidak menghasilkan enzim katalase, hasil uji $\mathrm{O} / \mathrm{F}$ menunjukkan no reaction, hasil uji TSIA menunjukkan hasil $\mathrm{K} / \mathrm{K}$ atau alkaline, non-motil, menghasilkan gelatinase, indol positif, hasil uji simmon's citrate negatif, uji urease menunjukkan hasil positif, dapat memfermentasi glukosa, sukrosa dan maltosa, dan bersifat aerob [20, 24].

Hasil identifikasi isolat ACB34a dan ACB55c menunjukkan kemiripan dengan Genus Actinomadura (Tabel 4). Hasil penyocokan dengan beberapa karakter kunci antara lain memiliki warna miselium subtrat berwarna merah, coklat, putih hingga krim, koloni berbentuk convex dengan tepi entire, uji gelatin positif, dapat memfermentasi gula arabinosa, glukosa, laktosa, maltosa dan sukrosa serta optimum pada suhu $20-30^{\circ} \mathrm{C}$ [17]. Kemudian memiliki hasil negatif pada uji aesculin, uji simmon's citrate negatif dan dapat tahan pada $\mathrm{NaCl} 3 \%$ namun di bawah 10\% [17-18].

Perbedaan utama karakter fenotip Actinomycetes asal rhizosfer tanaman tebu ada pada karakter morfologi koloni pada media SCA dan Oatmeal, katalase, indol, ornithin, kemampuan antibakteri, urease, simmon's citrate serta reduksi gula. Pada penelitian ini menggunakan pesenjajaran karakter dengan tetap menggunakan hasil double negative atau dapat disebut metode simple matching [25].

Koefisien similaritas simple matching umum digunakan pada ilmu bakteriologi dalam mengukur proporsi karakter yang sesuai, dapat memperbanyak input data sehingga karakter yang digunakan sebagai dasar semakin banyak (mendekati standar minimum 70 karakter). Penggunaan Clad97 pada penelitian ini dikarenakan prosedur preparasi dan pengolahan aplikasi ini mudah. Tidak memerlukan byte perangkat PC khusus seperti halnya MVSP, nilai output indeks similaritas berupa skala $0,00-1,00$ serta dalam penginputan data tergolong banyak yaitu maksimal 50 taksa dengan 200 karakter [6, 26].

Berdasarkan hasil similaritas tersebut dicocokkan dengan konsep taksospesies bakteri. Strain mikroba dapat dikelompokkan menjadi satu sepsies jika mempunyai indeks similaritas $\geq 70 \%$. Nilai koefisien korelasi fenetik $\geq 70 \%$ diasumsikan semakin dapat mewakili matrik similaritas serta dapat menjadi dasar kontruksi. Setiap bagan menunjukkan kesamaan spesies dan bagan diatasnya berarti berbeda spesies namun dalam satu genus [25, 27]. Hasil antara ACB34a lebih mirip dengan ACB55c, kemudian ACB44c memiliki indeks similaritas yang lebih dekat dengan ACB54c (Gambar 1). Namun penentuan satu spesies yang sama dalam suatu strain atau berbeda dalam suatu strain tertentu harus dilakukan uji lanjutan. Uji lanjutan bisa berupa penambahan karakterisasi sejumlah 70 karakter sebagai syarat ditentukannya spesies [28] atau dilakukan uji lanjutan juga berupa karakterisasi molekuler 16S rRNA. Karakterisasi gen 16S rRNA sering dilakukan karena memang daerah tersebut adalah daerah konservasi [29].

\section{KESIMPULAN}

Karakter fenotip pembeda keempat isolat Actinomycetes terpilih berdasarkan morfologi antara lain miselium aeral, miselium subtrat putih, dan pigmentasi. Perbedaan karakter fisiologi dan biokimia keempat karakter isolat adalah katalase, indol, ornithin, kemampuan antibakteri, urease, simmon's citrate, reduksi gula. Hubungan isolat ACB34a dengan ACB55c memiliki kesamaan 0,856 , kemudian isolat ACB54c dengan ACB44c memiliki kesamaan 0,788 serta tiap-tiap kedua isolat memiliki kesamaan senilai 0,7788 . Saran untuk penelitian lanjutan yaitu berupa uji lanjutan uji biokimia, fisiologi hingga identifikasi spesies berdasarkan sekuen gen 16S rRNA.

\section{UCAPAN TERIMA KASIH}

Terima kasih disampaikan kepada tim Mikrobiologi 2015, keluarga, semua dosen Jurusan Biologi FMIPA Universitas Negeri Surabaya.

\section{DAFTAR PUSTAKA}

[1] Aditi FY, Rahman SS, Hossain, MM (2017) A study on the microbiological status of mineral drinking water. The Open Microbiology Journal 11: 31-44.

[2] Khanna M, Renu S, Rup L (2011) Selective isolation of rare actinomycetes producing novel antimicrobial compounds. International Journal of Advanced Biotechnology and Research 2(2): 357-375.

[3] Geetanjali, Pranay J (2016) Antibiotic production by rhizospheric soil microflora A review. International Journal of Pharmaceutical Sciences and Research 7(11): 4304-4314.

[4] Krismawati H, Langkah Sembiring, Subagus W (2015) Streptomycetes penghasil antibiotik yang berasosiasi dengan rhizosfer 
beberapa spesies Mangrove. Plasma 1(2): 59-70.

[5] Sulistyanto WN, Trimulyono G (2019) Isolation and antibacterial activities of Actinomycetes from rhizosphere plant cane (Saccharum officinarum) on Escherichia coli and Staphylococcus aureus. Bioedukasi 17(1): 17-24.

[6] Julisaniah NI, Liliek S, Arifin NS (2008) Analisis kekerabatan Mentimun (Curcumis sativus L) menggunakan metode RAPDPCR dan isozim. Biodiversitas 9 (2): 99102.

[7] Mohseni M, Norouzi H, Hamedi J, Roohi A (2013) Screening of antibacterial producing Actinomycetes from sediment of the Caspian Sea. International Journal of Molecular and Cellular Medicine 2(2): 64-71.

[8] Prasetya IAW (2016) Isolasi dan karakterisasi bakteri kitinolitik endofit pada tanaman Bawang Merah (Allium ascalonicum) dan potensinya dalam menghambat pertumbuhan Fusarium oxysporum. Skripsi. Surabaya: Universitas Negeri Surabaya.

[9] Sateesh V, Naikpatil JL, Rathod (2011) Selective isolation and antimicrobial activity of rare Actinomycetes from Mangrove sediment of Karwar. Journal of Ecobiotechnology 2 (10): 48-53.

[10] Akond MA, Jahan MN, Nigar S, Farhana R, (2016) Effect of temperature, $\mathrm{pH}$ and $\mathrm{NaCl}$ on the isolates of Actinomycetes from straw and compost samples from Savar, Dhaka, Bangladesh. American Journal of Microbiology and Immunology 1(2): 10-15.

[11] Hemraj V, Diksha S, Avneet G (2013) A review on commonly used biochemical test for bacteria. Innovare Journal of Life Science 1(1): 1-7.

[12] Balai KIPM Kelas I Surabaya (2016) Protokol Instruksi Kerja. Sidoarjo: BKIPM Kelas 1 Surabaya.

[13] Barrow GI, Feltham RKA (1993) Cowan and Steel's manual for the identification of medical bacteria (Third Edition). UK: Cambridge University Press.

[14] Usman WS (2015) Bakteri asosiasi karang yang terinfeksi penyakit Brown Band (BRB) di perairan Pulau Barranglompo Kota Makassar. Skripsi. Makasar: Universitas Hasanuddin.

[15] Tantu W, Reiny AT, Sammy NJL (2013) Deteksi keberadaan bakteri Aeromonas sp. pada Ikan Nila yang dibudidayakan di karamba jaring apung Danau Tondano. Jurnal Budidaya Perairan 1(3): 74-80.

[16] Rohmanita SA, Ardyati T, Gama ZP, Nakagoshi N (2013) Identifikasi dan analisis Bacillus thuringiensis isolat lokal Jawa Timur yang berpotensi mengendalikan pertumbuhan larva Aedes aegypti. Biotropika: Journal of Tropical Biology 1(5): 226-230.

[17] Athalye M, M Goodfellow, Lacey J, White RP (1985) Numerical classification of Actinomadura and Nocardiopsis. Journal of Systematic Bacteriology 35 (1): 86-98.

[18] Holt JG, Sneath, PH, Krieg, Noel R (1994) Bergey's Manual of Determinative Bacteriology: Ninth Ed. USA: William and Walkins Baltimore.

[19] Pujiati, (2014) Isolasi Actinomycetes dari tanah kebun sebagai bahan petunjuk praktikum mikrobiologi. Jurnal Flore 1(2): $42-46$.

[20] Armaida E, Siti K (2016) Karakterisasi Actinomycetes yang berasosiasi dengan Porifera (Axinella spp.) dari perairan Pulau Lemukutan Kalimantan Barat. Jurnal Protobiont 5 (1): 68-73.

[21] Nurkanto A, Andria A (2015) Identifikasi molekular dan karakterisasi morfo-fisiologi Actinomycetes penghasil senyawa antimikroba. Jurnal Biologi Indonesia 11 (2): 195-203.

[22] Al-Alsaadi A, Noora MH, Eman MJ (2013) Isolation and identification of Streptomyces from different sample of soils. Journal of Biology and Medical Science 1: 31-36.

[23] Jawetz M, Adelberg (2007) Mikrobiologi Kedokteran. EGC: Jakarta. 165-174.

[24] Valenzuela-cova JF, Cudberro CP, Hector SH, Lorena CG, Carlos AVC, Hiram OD (2005) Biochemical identification and molecular characterization (PCR-RFLP) of Nocardia Isolates from sputum. Archives of Medicine Research 36: 356-361.

[25] Nursulistyarini F, Erny QA (2014) Isolasi dan identifikasi bakteri endofit penghasil antibakteri dari daun tanaman Binahong (Anredera cordifolia (Ten.) Steenis). Seminar Nasional XI Pendidikan Biologi FKIP UNS. Surakarta: UNS.

[26] Rahardi B, Arumingtyas EL, Firdaus W (2012) Constructing phenetic and phylogenetic relationship using Clad97. Journal of Tropical Life Science 2(1): 15-20. 
[27] Cohan FM (2002) What are bacterial species? Annual Review of Microbiology 56: 457-487.

[28] Kelley RW, Kellogg ST (1978) Computerassisted identification of anaerobic bacteria. Applied and Environmental Microbiology 35(3): 507-511.

[29] Zulaika E, Rositawati DN (2016) Keanekaragaman bakteri pelarut fosfat dari kawasan Mangrove Wonorejo dengan pendekatan taksonomi numerik fenetik. Seminar Nasional Biodiversitas VI, Surabaya 3 September 2016. 